\title{
Research on Course Teaching of Tax Practice based on the Theory-Practice Integration Teaching Method
}

\author{
Wenxia Li \\ Business College, University of Science and Technology of Wuchang, Wuhan, 430223, China
}

Keywords: Theory-practice integration, Tax Practice, Course teaching, Strategies

\begin{abstract}
The theory-practice integration teaching method is a new kind of teaching method. Employing this teaching method in the course teaching of Tax Practice is significant for students' study and their jobs and development. This paper will firstly introduce theory-practice integration teaching method's concept, then it will analyze the importance of employing this teaching method in the course teaching of Tax Practice. In the next part of this paper, the author will discuss the building strategies of Tax Practice based on the theory-practice integration teaching method from some aspects, such as clarify teaching concepts, build teaching systems, introduce case teaching, enhance cooperation between colleges and firms and strengthen the teaching staff.
\end{abstract}

\section{Introduction}

Tax Practice course is an important course for students of finance and economics in higher vocational colleges. Students of finance and economics must master tax practice for their future accounting jobs. Tax Practice course is closely connected to current policy and theory as well as real work. There are some problems in our current Tax Practice course teaching, such as teachers' teaching emphasizes theory rather than practice, and emphasizes computation of tax amount rather than tax declaration. Traditional teaching mode, which focuses on theory, is easy to make students feel boring, creates a gap between students' ability and the requirements of real tax declaration. This has a bad influence on students' employment. The theory-practice integration teaching method combines theory and practice. To apply the theory-practice integration teaching method in Tax Practice course could improve its teaching quality.

\section{The concept of theory-practice integration teaching mode}

The theory-practice integration teaching mode emphasizes not only combining theory with practice, but also cultivating students' practical ability. It is based on theory, emphasizes cultivating students' comprehensive ability. It helps boost students' comprehensive development through combining theory and practice. ${ }^{[1]}$ The theory-practice integration teaching mode requires teachers to teach students related literacy knowledge and skills in practice. This teaching mode changes traditional old fashioned education means, improves students' initiative. Through making students practice more, it makes students master theory as well as enhance their practical ability. Therefore it helps improve students' study results.

The necessity of implementing the theory-practice integration teaching mode in Tax Practice course

To implement the theory-practice integration teaching mode is necessary for reforming Tax Practice course, improving whole teaching quality and cultivating society-oriented talents.

\section{To meet the talents needs of society}

Higher vocational colleges are to cultivate society-oriented and practical talents. Practical talents mean those talents who can apply their expertise and skills to social practice, in order to meet firms' 
production and management needs. Therefore to implement the theory-practice integration teaching mode can meet the skilled talents needs of society.

\section{To meet the reform needs of Tax Production course}

Tax Production course combines theory and practical operation closely. To cultivate society-oriented talents, higher vocational colleges need to teach students taxation theories as well as ask students to finish related work on the job. Currently many higher vocational colleges of finance and economics have opened courses about the tax law and practical training. At the same time many software firms have studied and designed some tax teaching software which can simulate tax declaration in teaching. To some extent, these teaching resources ensure teaching qualities. However current teaching methods usually teach theories first, then perform practical training, and let students practice at last. These methods cost too much time in teaching, resulting in limiting teaching results. To perform the theory-practice integration reform in Tax Practice course is of great significance.

\section{Tax Practice course's teaching status in China's higher vocational colleges}

Currently China's Tax Practice course emphasizes more on explaining legal provisions of tax laws. But in real work the practical process of paying tax is barely reflected in the teaching system. This teaching mode does not help develop students' practical ability. Tax work needs a lot of practice. Legal provisions are not enough for it. The education and teaching in higher vocational colleges need to emphasize more on developing students' tax practical ability, build a set of teaching system to combine theory and practice, and improve students' practical ability, in order to meet the demands of skills on practitioner by the social economy growth. At the same time, the teaching of Tax Practice course is more difficult than other courses' teaching. Teachers' knowledge and ability are lack of effective integration. Many teachers have never been engaged in tax practice. This results that whole teaching process is lack of real experience and is not helpful for students to absorb tax knowledge ${ }^{[2]}$. Regarding for this, the author, based on abundant experience in Tax Practice course teaching, will discuss the building strategy of theory-practice integration for Tax Practice course from the following aspects.

\section{The teaching design of Tax Practice course based on the theory-practice integration teaching method}

\section{To determine teaching ideas}

To carry out the theory-practice integration teaching of Tax Practice course, we should determine the idea of master the practical content of Tax Practice as the whole teaching process, regard develop students' practical ability as its core, and highlight the teaching features of higher vocational education.

\section{To build the theory-practice integration teaching system}

In building course system, we shall enhance the cooperation with social firms and experts, set up teaching targets and clarify students' studying field and content based on students' cognitive level and psychology features. First, the knowledge targets to realize the theory-practice integration of $\operatorname{Tax}$ Practice shall include: 1. learn China's tax law; 2. learn China's tax paid by various firms; 3. calculate tax amount precisely; 4. finish tax declaration in accordance with related requirements. Second, ability targets students shall meet include: 1. identify related vouchers and process tax related business; 2 . be clear of the computation methods of tax amount which shall be paid by firms and be able to calculate precisely; 3 . be able to fill in tax application form and declare tax; 4. be able to dissolve various problems in the whole tax process. Finally the quality targets students shall meet include: 1 . strict working attitude; 2 . the ability to communicate and cooperate; 3 . self-learning ability and extension spirit; 4. good language presentation skills and the ability to reflect and summarize. Higher vocational colleges shall emphasize on building scientific teaching system from tax theory 
and practice. At the same time they shall highlight the practice teaching to build foundation for students' future employment and development.

\section{To equip corresponding teaching files}

In current Tax Practice course teaching of higher vocational colleges, theory classes will be arranged first and practice will be second. While practice teaching materials are printed by higher vocational colleges. Thus in implementing theory-practice integration, colleges shall equip corresponding teaching materials. For example, in the talents training scheme of Tax Practice course, skills training shall be highlighted and practice classes shall be more. Current Tax Practice teaching materials have too many theories and they are quite different. Thus colleges shall pay more attention to composing Tax Practice teaching material based on the theory-practice integration.

\section{To equip necessary practice devices and teaching zone}

In traditional Tax Practice teaching mode, classrooms and laboratories are separate. Some vocational colleges even have their Tax Practice classes finished in classrooms. This teaching mode usually neglects practice, thus students are not sure about the difference between theory classes and practice classes and finish their practice class in the form of homework. It limits Tax Practice course's teaching quality. Therefore in theory-practice integration teaching, colleges shall equip special teaching zones and highlight teaching atmosphere. In this teaching zone, colleges shall arrange enough space for students to practice with corresponding devices after learning theory. Through dividing special teaching zone and equipping necessary devices, it can improve students' initiative and improve teaching quality.

\section{Pay more attention to the case teaching method}

In Tax Practice teaching, colleges shall take advantage of China's large, medium and small enterprises' real tax types and employ real cases to teach students taxes planning, calculation and reporting. And teachers shall design study tasks in line with study content, and use modern teaching means to teach. In teaching process, teachers shall set up teaching context, tell students the details about firms to enter, products or business domains of firms, and tell them what economic affairs they will meet in future accounting work before carry out entire teaching activities. Second, teachers shall focus on introducing project tasks. Teachers shall tell students tax knowledge to use in dealing with related economic affairs. Before classes, teachers could deliver some cases to students and let students deal with these issues with their own tax knowledge. At this step, teachers shall guide students and evaluate and summarize their task results. Then teachers shall summarize key tax knowledge in this economic affair to build foundations for students' future employment.

\section{To strengthen higher vocational colleges' cooperation with firms}

Higher vocational colleges shall strengthen their cooperation with firms, enhance their communications with tax accountant firms and accounting firms, and create more practical chances for students to improve their professional skills and abilities through practice. At the same time, colleges shall let students deal with tax related business based on various economic activities, such as declare tax to tax authorities and pay tax to banks, when colleges are cooperating with firms. In this way, students will be able to learn how to calculate tax amount and declare tax and so on, thus their ability to deal with tax will be improved.

\section{To improve students' ability to operate the tax practice}

First, colleges shall strengthen the popularization of business to students, letting them learn some information about various firms and firms' economic procedures. Through learning related knowledge, students will better understand firms' management and operation, thus they will better understand tax practice's operation details. Second, higher vocational colleges shall strengthen students' tax practice. There are two forms of tax practice operations in firms: manual operation and network operation, which means using related tax software to deal with tax ${ }^{[4]}$. Manual operation 
could help students learn tax declaration forms' structures, tax data filling methods, and various data's purposes and sources. Network operation is mainly about simulating tax declaration's practical operation. Through combining manual operation and network operation, the theory-practice teaching mode helps improve students' tax practice skills.

\section{To popularize tax laws and regulations}

First colleges shall take advantage of linkages with firms and tax authorities to introduce tax laws knowledge to students and publicize them regularly. Second, colleges could hire some workers in tax authorities to introduce some real tax related cases to colleges and analyze these real cases to strengthen students' tax sense and develop their vocational ethics.

\section{To improve teachers' tax practical operation ability and build a better teaching team}

Teachers play a key role in teaching tax knowledge. The theory-practice integration teaching mode demands more about teachers' comprehensive abilities in higher vocational colleges. Teachers of Tax Practice in traditional teaching mode are not good at practice and could not understand tax's importance to the whole country. Therefore the teachers using the theory-practice integration teaching method shall improve their own tax practical level, communicate more with firms, deal with tax practice operation carefully, and accept tax authorities' examination. Then they will be able to bring their personal experience into teaching activities and improve teaching quality ${ }^{[5]}$. Besides improving teachers' tax practical operation ability, colleges shall build a better teaching team. First, colleges could train all teachers of Tax Practice course, transform their teaching ideas and change the traditional teaching mode. Second, colleges could hire some technical worker with high theory level and abundant practical experience as part time teachers so that these teachers could teach students some practical experience to improve students' practical ability.

\section{Conclusion}

In summary, to implement the theory-practice teaching mode in Tax Practice course could improve teaching quality and help students learn tax related knowledge. Higher vocational colleges shall improve teaching environment and devices, build a scientific teaching system, and build a better teaching team to improve the teaching efficiency of Tax Practice course, thus cultivate more applied talents for the entire society and make its due contribution.

\section{Acknowledgments}

This paper is the project of Hubei provincial level higher education teaching research in 2014, Which name is The Creation of and Research on Financial Professionals Cultivation System from the Perspective of Business Ethics, project No.: 2014416.

\section{References}

[1] Tao Rongquan. The course design of Tax Practice in higher vocational colleges in theory-practice integration teaching mode. Golden Times, 2013,(8):170-170.

[2] $\mathrm{Lu}$ Yan. Teaching reform and discussion of tax related courses in higher vocational colleges. China Township Enterprises Accounting, 2014,(12):279-279,280.

[3] Lei Xia. The Tax Practice course design in theory-practice integration in higher vocational colleges . Golden Times, 2013,(8):186-186,189.

[4] Dou Bifeng. Issues concerned with the theory-practice integration teaching mode in Tax Practice course . Golden Times, 2013,(8):165-165.

[5] Sun Diehao. Reform exploration of tax laws related courses based on the theory-practice integration teaching mode . Management \& Technology of SME, 2013,(9):269-270. 
